\title{
HEDONISME DALAM CERITA PENDEK SUATU SORE \\ KARYA NURUL ARIFIN
}

\section{Budi Agung Sudarmanto \\ Email: budi_agung_s@yahoo.com \\ Balai Bahasa Sum-Sel}

\begin{abstract}
Abstrak - Penelitian ini bertujuan untuk mendeskripsikan fenomena hedonisme yang ada di dalam cerita pendek Suatu Sore karya Nurul Arifin. Hedonisme adalah sebuah pandangan yang menjadikan kesenangan (pleasure) sebagai tujuan hidup. Hedonisme bisa dilihat sebagai sebuah pandangan negatif dan pandangan positif. Teori yang digunakan di dalam penelitian ini adalah teori strukturalisme. Teori strukturalisme memandang konsep fungsi memegang peranan penting. Dalam penelitian ini menggunakan metode deskriptif analisis, yaitu menganalisis data dengan cara mendeskripsikannya berdasarkan teori yang ada. Hasil dari analisis yang sudah dilakukan adalah bahwa hedonisme yang dipandang dari sisi negatif ditandai dengan perilaku seksual dan perilaku konsumtif sedangkan pusat perhatian dan kebersamaan menandai pandangan positf dari hedonisme.
\end{abstract}

Kata kunci: hedonisme, feminisme, cerita pendek

Abstract-. This research aims to describe the phenomenon of hedonism in the short story of An Afternoon by Nurul Arifin. Hedonism is a view that makes pleasure as the purpose of life. Hedonism can be seen as a negative and a positive outlook. The theory used in this study is the theory of structuralism. Structuralism theory views the concept of function as having an important role. In this study using descriptive analysis method, which is analyzing data by describing it based on existing theories. The result of the analysis that has been done is that hedonism which is seen from the negative side is characterized by sexual behavior and consumptive behavior while the center of attention and togetherness marks a positive view of hedonism

Keywords: hedonism, feminism, short stories

$\vec{a}$

\section{PENDAHULUAN}

Genre sastra terdiri atas tiga jenis, yaitu drama, prosa, dan puisi (Wellek dan Warren, 2014:277). Salah satu jenis prosa adalah cerita pendek, selain novel. Cerita pendek adalah bacaan singkat yang dapat dibaca sekali duduk dalam waktu setengah sampai dua jam yang memiliki genre efek tunggal, karakter, plot, dan (latar) setting yang terbatas, tidak beragam dan kompleks. Di dalam cerita pendek, pengarang tidak melukiskan seluk beluk kehidupan tokohnya secara menyeluruh. la hanya menampilkan bagian-bagian penting kehidupan tokoh yang berfungsi untuk mendukung cerita, selain juga untuk menghemat penulisan cerita mengingat keterbatasan ruang yang ada (Poe dikutip Stanton, 2012:79). 
Suatu Sore karya Nurul Arifin adalah satu di antara contoh cerita pendek. Cerita pendek ini adalah bacaan yang dapat dibaca sekali duduk dengan memiliki karatkter, plot, dan latar yang terbatas, yang tidak beragam dan kompleks. Keduanya menggambarkan kehidupan kosmopolitan para perempuan mapan yang mampu mengatur kehidupan pribadinya dengan maksimal. Dengan bergaya hidup kelas menengah ke atas memungkinkan para pelaku di dalam cerita pendek ini merealisasikan kebutuhan yang diinginkannya.

Salah satu fenomena cerita pendek Suatu Sore karya Nurul Arifin ini adalah kehidupan yang hedon. Kehidupan para hedonis ini berpangkal dari sebuah paham yang disebut hedonisme. Secara umum, hedonisme memiliki makna pandangan hidup yang menganggap bahwa kesenangan dan kenikmatan materi adalah tujuan utama hidup. Pengikut paham hedon ini ini beranggapan bahwa hidup hanya satu kali. Kesempatan hidup satu kali ini ingin mereka merasakan dengan senikmat-nikmatnya. Mereka juga menginginkan kehidupan yang sebebasbebasnya. Pandangan seperti ini muncul semenjak zaman Yunani Kuno, berdasarkan pandangan Epikuros. Pandangan Epikuros yang paling rinci mengenai hedonisme adalah bahwa bergembiralah engkau hari ini, puaskanlah nafsumu karena esok engkau akan mati (Dewojati, 2010:16).

Cerita pendek Suatu Sore karya Nurul Arifin berkisah tentang tiga perempuan muda, lajang, mapan, kaya, pergaulan luas, bebas yang membentuk kelompok yang diberi nama BITCH kepanjangan dari beautiful, intelligent, talented, charming and 'hot'. Dari nama ini saja sudah menyiratkan sebuah identitas kebebasan dan perlawanan (minimal daya tawar yang kuat) terhadap kaum laki-laki. Di usia matang mereka, mereka tidak berpikir tentang pernikahan meski masing-masing memiliki pasangan yang bisa diajak berbagi rasa. Pasangan mereka pun tidak terbatas berasal dari dalam negeri. Azha memiliki Black dan Sendre memiliki Massimo dari Italia. Begitu bebas mereka mendapatkan apa yang mereka mau, termasuk kebutuhan seksual dan hal-hal lain yang mendukung kebutuhan gaya hidup seksual mereka. Mereka sudah terbiasa dengan pakaian-pakaian pendukung kehidupan seksual mereka.

Pemilihan cerita pendek berjudul Suatu Sore karya Nurul Arifin ini didasari oleh keberadaan isi dari cerita pendek tersebut yang kental dengan permasalahan kehidupan hedonis yang dilakukan oleh perempuan. Hal ini sesuai dengan tujuan penelitian yang dilakukan, yaitu menguak keberadaan sisi hedonisme yang ada di dalam cerita pendek tersebut. Oleh karena itu, penelitian ini perlu untuk dilakukan. Masalah dari penelitian ini dibatasi pada permasalahan hedonisme yang terdapat dalam cerita pendek Suatu Sore karya Nurul Arifin.

\section{METODE PENELITIAN}

Penelitian ini menggunakan metode deskriptif analisis. Metode deskriptif analisis dilakukan dengan mendeskripsikan fakta-fakta yang kemudian disusul dengan menganalisis. Analsis telah diberikan arti tambahan, tidak semata-mata menguraikan melainkan juga memberikan pemahaman dan penjelasan sesuai dengan yang dibutuhkan (Ratna, 2015:53).

Teori yang digunakan di dalam penelitian ini adalah teori strukturalisme. Teori strukturalisme memandang konsep fungsi memegang peranan penting. Unsur-unsur sebagai ciri khas teori ini dapat berperan maksimal dengan adanya fungsi yaitu dalam rangka menunjukkan antarhubungan unusr-unsur yang terlibat. Bisa dikatakan struktur lebih dari sekadar pemahaman bahasa sebagai medium, karya sastra lebih dari sekadar penjumlahan bentuk dan isinya. Unsur-unsur memiliki fungsi yang berbeda- 
beda, dominasinya tergantung jenis, konvensi, dan tradisi sastranya (Ratna, 2015:75).

Teknik pengumpulan data yang digunakan adalah teknik dokumentasi. Yakni, mencari data mengenai hal-hal berupa catatan, transkrip, buku, surat kabar, majalah, prasasti, notulen, agenda dan sebagainya. Metode dokumentasi dapat diartikan sebagai suatu cara pengumpulan data yang diperoleh dari dokumen-dokumen yang ada atau catatancatatan yang tersimpan, baik itu berupa catatan transkrip, buku, surat kabar, dan lain sebagainya (Margono, 2007). Metode ini adalah mengumpulkan data dengan cara mendokumentasikan data berdasarkan sumber data yang sudah ditentukan.

Analisis data adalah upaya yang dilakukan dengan cara bekerja dengan data, mengorganisasikan data, memilah-milahnya, mencari dan menentukan pola, menemukan apa yang penting dan apa yang dipelajari, dan memutuskan apa yang dapat diceritakan kepada orang lain (Bogdan dan Biklen dalam Moleong, 2016:248). Teknik analisis data yang digunakan dalam penelitian ini adalah analisis isi (content analysis), yaitu mencatat lambang atau pesan secara sistematis, kemudian memberi interpretasi. Dengan menggunakan teknik analisis data ini peneliti bekerja melalui transkrip yang memberikan kode-kode untuk menspesifikkan karakteristik-karakteristik dalam teks (Dawson, 2010:145).

Langkah-langkah yang dilakukan dalam teknik analisis data dalam penelitian ini adalah sebagai berikut: (a) membaca cerita pendek Suatu Sore karya Nurul Arifin secara keseluruhan; (b) memahami isi cerita pendek Suatu Sore karya Nurul Arifin yang berkaitan dengan hedonisme; (c) mencatat data-data dari cerita pendek Suatu Sore karya Nurul Arifin yang berkaitan dengan hedonisme; (d) menganalisis isi cerita pendek Suatu Sore karya Nurul Arifin yang berkaitan dengan hedonisme; (e) mengelompokkan data yang berkaitan dengan hedonisme; dan (f) Melakukan analisis isi (konten), yaitu mencatat lambang atau pesan secara sistematis, kemudian memberi interpretasi dari data yaitu cerita pendek Suatu Sore karya Nurul Arifin berdasarkan hedonismenya.

\section{HASIL DAN PEMBAHASAN}

Seperti yang disampaikan pada bagian kerangka teori tentang hedonisme dikatakan bahwa hedonisme adalah sebuah pandangan, gaya hidup, budaya tentang bagaimana seseorang atau sekelompok masyarakat berusaha untuk mengejar, menjalani, dan menikmati kesenangan (pleasure) sesuai dengan yang diinginkannya. Kesenangan adalah tujuan hidup mereka. Apa pun dilakukan untuk dapat menggenggam atau meraih kesenangan (pleasure) tersebut. Dengan kondisi seperti ini memunculkan berbagai kondisi yang kurang biasa di dalam masyarakat. Para hedonis (pelaku hedonisme) dipandang berlebihan atas apa yang dilakukannya. Meskipun demikian, hedonisme -dengan slogan meraih kesenangannya- bisa menjadi pendorong atau motivator untuk mencapai cita-cita mulia. Karena itulah di dalam hedonisme ada yang memandangnya sebagai hedonisme negatif dan hedonisme positif (lihat Verhooven, 2003:437-440; Brax, 2009:195196; Weijers, 2012:16-17; Bertens, 2013:183-184; Kunzmann, dkk., 2005: 576; Dewojati, 2010:17).

Kehidupan hedonis yang digambarkan di dalam cerita pendek Suatu Sore karya Nurul Arifin dialami oleh sekelompok perempuan yang menjadi sorotan utama di dalam cerita ini. mereka adalah Azha, Sendre, dan Rea. Kehidupan yang mereka jalani begitu enak, membahagiakan, dan pasti tidak memiliki kekurangan suatu apa, terutama dari sisi material. Mereka tiga perempuan muda yang mapan, terpandang, kaya, cantik, pintar, berpikiran maju dan 
bebas, menginginkan (dan sekaligus merealisasikan) kebebasan dan kesenangan yang didambanya. Dalam cerita pendek ini menggambarkan kebiasaan yang mereka lakukan di waktu luang yang mereka miliki.

Dikatakan bahwa hedonisme dibagi dua yaitu hedonisme negatif dan hedonisme positif. Untuk itu, selanjutnya, pembahasan berikut ini akan dilakukan dengan mendasarkan kepada kedua jenis hedonisme tersebut, yaitu hedonisme negatif dan hedonisme positif.

\section{a. Hedonisme Negatif}

Para tokoh yang ada di dalam cerita pendek Suatu Sore karya Nurul Arifin ini menjalani hedonisme negatif di dalam perilaku seksual mereka. Apa yang mereka lakukan mewakili sebuah gaya hidup hedon yang tidak biasa dilakukan oleh manusia kebanyakan. Apa yang dilakukan tidak bisa dengan mudah diterima secara moral. Para tokoh di dalam cerita pendek ini belum mengikatkan diri secara sah di dalam biduk pernikahan. Akan tetapi, orientasi seksual di dalam kehidupan mereka menunjukkan kebebasan di dalam memilih dan juga melakukan aktivitas seksual sesuai dengan yang diharapkan.

Hedonisme negatif di dalam karya sastra cerita pendek Suatu Sore karya Nurul Arifin lebih banyak mengeksplotasi perilaku seksual dan perilaku konsumtif para tokoh yang terlibat di dalam cerita tersebut. Perilaku seksual ditandai dengan pemilihan pasangan seksual, cunnilingus, dan waxing. Sedangkan perilaku konsumtif dijelaskan dengan perilaku belanja (shopping) dan perilaku kongkokongko (hang-out) mereka yang menyedot rupiah tidak kecil dari kantor mereka.

\section{1) Perilaku Seksual}

Perilaku seksual pada bagian pembicaraan hedonisme negatif ini membahas tentang pemilihan pasangan seksual, cunnilingus, dan waxing. Masingmasing bagian akan dijelaskan berikut ini.

\section{a) Pemilihan Pasangan Seksual}

Memilih pasangan akan memberi harapan kesenangan di dalam melakukan aktivitas seksual. Setidaknya ini yang dilakukan oleh Azha dan Sendre yang memilih untuk memiliki pasangan seksual bule. Azha memiliki pasangan yang bernama Black sedangkan Sendre memiliki pasangan bule yang bernama Massimo. Disebut dengan pasangan seksual karena masing-masing belum mengikatkan diri untuk secara sah di dalam biduk pernikahan. Mereka pun tidak menunjukkan kejelasan jalan menuju jenjang pernikahan. Akan tetapi, kedua pasangan ini menikmati kebersamaannya. Yang banyak diekspos di dalam cerita pendek ini adalah kebersamaan mereka di dalam percintaan atau aktivitas seksual di antara mereka.

Azha mempersiapkan diri di dalam upaya membina relasi dengan pasangan bulenya. Apa yang dilakukan bukan saja untuk memanjakan Black tetapi juga mengharapkan kesenangan yang akan diterima dari relasinya dengan Black. Memiliki pasangan orang asing (bule) dianggap memiliki kelebihan kelas sosial yang lebih tinggi daripada memiliki pasangan pribumi. Kondisi seperti ini menjadikan Azha bisa menjadi sorotan yang lebih di dalam pergaulannya. Dengan kata lain dia akan menjadi pusat perhatian di lingkungannya. Dari sisi hedonisme, menjadi pusat perhatian adalah keingian yang selalu ingin dicapainya. Kesenangan (pleasure) di sisi ini menjadi kepuasan tersendiri yang tidak bisa dihindari oleh para hedonis.

.... Wuihh... pasti Black langsung mengerjap gelisah, tak tahan untuk segera menerkam. Hihi... Black adalah pacar Azha yang bukan berarti hitam meski ia dipanggil Black karena kulitnya justru sangat putih untuk ukuran cowok. (Arifin, 
2003:38).

Secara seksual, Azha menemukan kesenangan melakukan aktivtas seksual dengan Black. Azha dan Black adalah pasangan yang bebas dari ikatan pernikahan. Karena itu, apa yang mereka cari hanyalah kesenangan, kebebasan di dalam melakukan aktivitas seksualnya. Ikatan pernikahan belum menjadi prioritas lebih utama bagi mereka dibandingkan dengan aktivitas seksual.

Sahabat Azha, anggota dari BITCH, yaitu Sendre juga memiliki pasangan orang asing (bule) yang bernama Massimo. Sendre pada akhirnya memutuskan untuk menjalin relasi dengan Massimo karena latar belakang Massimo yang ekspatriat. Bukan sekadar posisi Massimo yang konsultan di tempat Sendre bekerja tetapi, lebih dari itu, Massimo adalah yang berasal dari luar negeri. Kisah Azha yang memilih Black sebagai pasangannya yang berasal dari luar negeri dan Sendre yang memilih Massimo sebagai pasangannya membuat keduanya menjadi pusat perhatian di lingkungannya. Tentunya, tidak banyak yang bisa mendapatkan kesempatan untuk bersanding dengan bule. Dan ketika hal itu bisa dilakukan, ini artinya para pelakunya memiliki kelebihan yang tidak dimiliki oleh orang lain. Kesenangan seperti inilah yang bisa mencirikan kehidupan hedonis bagi para pelakunya. Dalam kaitan dengan perilaku seksual, sebuah mitos mengatakan bahwa bule memiliki kualitas seksual yang lebih tinggi dibandingkan dengan pribumi. Untuk mendukung argumen tersebut akan lebih banyak dibicarakan pada bagian b) cunnilingus dan c) waxing.

Pasangan Sendre adalah bule.

Pertemuan mereka berawal dari

pertemuan kebetulan karena

Massimo sering mengadakan kerja sama dengan kantor Sendre. Sendre adalah senior public relation sebuah perusahaan minyak. Sementara Massimo sendiri adalah konsultan dari anak perusahaan yang berada di bawah naungan perusahaan minyak tempat Sendre bekerja.

Sendre sendiri memiliki posisi yang bergengsi di perusahannya. Senior public relation adalah posisi yang layak diperhitungkan bagi siapa pun yang berhadapan dengan dirinya. Perusahaan minyak adalah jaminan keberadaan di mana Sendre bekerja. Dengan kondisi seperti ini tidaklah mengherankan bila Sendre memiliki standar tertentu di dalam memilih dan menentukan dengan pria siapa yang layak untuk mendampingi dirinya, di dalam beraktivitas sosial dan seksual yang dijalaninya.

\section{b) Cunnilingus}

Dengan mendapatkan pasangan seksual bule, Sendre memperkenalkan satu istilah yang sebenarnya umum di dalam seksologi tetapi bagi kalangan belum sepenuhnya sudah dikenal dengan baik. Sendre membawa istilah cunnilingus. Sebenarnya hal ini terasa kurang meyakinkan apabila para perempuan di dalam kelompok BITCH itu tidak mengenal istilan ini. Mengapa demikian? Status sosial mereka semestinya sudah mengenal istilah ini. akan tetapi, pada kenyataannya Azha belum mengenalnya. Terlepas dari para tokoh yang mungkin belum mengenal istilah ini tetapi mereka semua justru sebenarnya sudah mempraktekkannya.

"Yoi, aduh asyik banget 'kerjaan' kita hari ini. Cunnilingus-nya si Massimo bener-bener bikin gue benerbener...agh..ugh..ughhh...," Sendre merem melek. Asli merem melek keenakan gitu, kaya Cookie kalau dielus-elus Rea. Cookie adalah anjing cow-cow kesayangan Rea di 
rumah. (Arifin, 2003:40).

Apakah cunnilingus itu? Azha yang pada awalnya begitu penasaran dengan istilah aktivitas seksual yang dilakukan Sendre menjadi merasa biasa saja. Tentu saja dia tidak lagi merasa istimewa karena dia sudah terbiasa mempraktekkannya. Cunnilingus adalah istilah khusus dari istilah seks oral (oral sex), yang sudah biasa dilakukan oleh Azha, dan juga Rea.

"Aduh, bilang aja oral seks, sampai bingung gue," kata Azha. "Kalau itu sih gue jagonya, gak cuma si Black, gue juga jago cunnilingus- cunnilingusan." (Arifin, 2003:41).

Pengalaman Sendre akan cunnilingus menjadi begitu fenomenal di dalam cerita ini. Dialah yang menginisiasi istilah dan pengalaman tentang cunnilingus ini. Pengalaman seksual dengan menggunakan cunnilingus sebagai saranya menunjukkan betapa ampuhnya aktivitas seksual mereka. Cunnilingus yang dilayankan oleh Massimo menjadikan Sendre begitu melayang ke langit ketujuh. Ini semua adalah kesenangan (pleasure) yang bisa jadi hanya sesaat. Bisa dimaklumi kesenangan ini hanya sesaat karena semua hal bisa saja terjadi. Dengan kondisi tanpa ikatan pernikahan yang resmi seperti yang mereka jalani, kesempatan untuk memiliki kebersamaan lebih lama menjadi sesuatu yang tidak pasti.

"Yang gue rasa, Massimo benerbener nyervis gue, deh. Asli enak banget. Dan dia telaten banget. Dijilat semua sampai die dapetin Gspot gue. Coba, gimana gue gak termehe-mehe," Sendre merem melek lagi. (Arifin, 2003:40).

Rea ternyata juga menjalani aktivitas seksual dengan memanfaatkan cunnilingus sebagai medianya. Baginya, cunnilingus adalah bagian penting yang tidak dilewatkan setiap kali melakukan aktivitas seksual. Untuk itu, dia selalu melakukannya di dalam setiap episode aktivitas seksualnya.

"Trus, kalo lo having sex emang selalu pake cunnilingus dulu, Sen? Tanya Rea.

"lya dong Bu Guru, enak lagi. Lo gak pernah?

"Gak pernah sekali," sahut Rea enteng. Mereka tertawa. Itu artinya selalu. (Arifin, 2003:40).

\section{c) Waxing}

Sebenarnya waxing di dalam cerita ini hanyalah baru sebatas wacana atau saran dari Sendre untuk dilakukan oleh Rea. Asumsinya, Sendre sudah melakukan waxing sementara Rea belum.

"Eh, tau gak, biar cunnilingus tambah seru, jangan lupa nge-waxing jembi," tambah Sendre dengan berbisikbisik, tapi tidak lupa dengan nada penuh semangat khas Sendre.

"Aku takut, Send," kata Rea sambil mengelus-elus....

"Enggak usah takut, kan tinggal ke salon atau klinik. Yang ngerjain professional lagi. Gue kemarin di-waxing Brazilian cut, wihh...seru!" (Arifin, 2003:42-43).

Waxing adalah salah satu trend masa kini yang disarankan dicoba. Salah satu alasan dilakukannya waxing adalah untuk lebih meningkatkan kenikmatan dan kepuasan di dalam melakukan aktivitas seksual. Karena itulah Sendre begitu antusias menyarankan sahabatnya untuk melakukan Brazilian waxing, yaitu membersihkan (menghilangkan) bulu di sekitar area sensitif seksual perempuan. Bisa dibayangkan 
bagaimana kondisi di seputar area seksual perempuan yang tanpa bulu sama sekali.

Apa yang dilakukan dengan waxing ini hanyalah semata-mata untuk mengeksplorasi, juga eksperimentasi, kegiatan seksual yang dilakukan. Dengan kata lain, keinginan untuk melakukan waxing adalah untuk mendapatkan kesenangan (pleasure) yang lebih daripada mereka yang tidak melakukan waxing. Kesenangan (pleasure) semata yang ingin diraihnya. Itulah hedonisme yang dijalankan oleh para hedonis.

Bule menyukai waxing di dalam aktivitas seksual mereka. Hal ini bisa dipahami karena di luar negeri waxing telah menjadi hal yang biasa, bahkan sudah menjadi tuntutan hidup di dalam beraktivitas seksual. Untuk itu, Black dan Massimo merasa ada yang kurang apabila Azha dan Sendre tidak melakukan waxing sebagai persyaratan persiapan untuk aktivitas seksual mereka.

\section{2) Perilaku Konsumtif}

Sikap konsumtif yang bisa dipaparkan dari cerita pendek Suatu Sore karya Nurul Arifin adalah perilaku belanja (shopping) dan perilaku kongkokongko (hang-out). Shopping menjadi kebutuhan yang sangat penting bagi perempuan untuk menunjang penampilannya. Perilaku hang-out (pergaulan) juga akan menentukan status sosial yang disandangnya. Penampilan adalah modal untuk menjadi pusat perhatian. Pusat perhatian adalah bagian dari hedonisme (Amstrong dalam Trimartati, 2017:21-22).

\section{a) Belanja (Shopping)}

Perilaku belanja (shopping) Azha mendominasi pembicaraan perbelanjaan di dalam cerita ini. Apa yang dilakukan oleh Azha sudah menjadi suatu kebiasaan yang pada akhirnya dipahami oleh orangprang di sekitarnya. Belanja yang sudah biasa dilakukannya. Sebagai sebuah kegemaran (hobi) dan kesenangan menjadikan Azha begitu mudah ditandai pada saat dia tidak ada di tempatnya.

Yang pertama muncul Azha, penulis dan presenter TV yang kondang karena gayanya yang cool dan smart. Saking coolnya, dia suka dituduh lesbi. Hobby banget belanja, makanya suka kesasar ke Plaza Senayan kalau ada sale. Artinya orang susah menghubungi dia kalau dia lagi belanja, even produser TV-nya sendiri. Jadi anggap aja dia kesasar dan menghilang. Seperti biasa, dia muncul dengan kantong-kantong belanjaan. (Arifin, 2003:38).

Hasil belanjaan Azha menandai selera imajinatif yang dimiliki oleh Azha. Hasil pengejaran (hunting) belanja Azha kali ini didominasi dengan kebutuhan pakaian dalam yang akan dipakai sebagai persiapan untuk bertemu dengan pasangannya. Meskipun demikian, bukan tidak mungkin keinginan untuk mendapatkan kesenangan (pleasure) dalam berbelanja akan menghasilkan belanjaan yang beragam dan pastinya mahal.

Sambil menunggu teman-temannya,

Azha menikmati hasil belanjaanya.

Pertama, BH dan CD. Hmm...dia sudah membayangkan bagaimana tampilan dirinya dengan $\mathrm{BH}$ dan $\mathrm{CD}$ dengan motif baju tentara tadi. (Arifin, 2003:38).

Jenis belanjaan Azha bermacam-macam. Selain $\mathrm{BH}$ dan $\mathrm{CD}$ ternyata masih banyak belanjaan lain yang dibelinya. Azha tidak perduli kalau barang belanjaan yang diincarnya tersebut adalah barang discount, malah dia menunggu adanya discount tersebut. Yang penting adalah dia mendapatkan komoditas yang diinginkannya.

Azha kembali mengaduk belanjaannya. la meraih sebuah 
blouse putih yang sudah lama diidamidamkannya.

Azha membentangkannya dengan penuh semangat. Meski sudah lama menginginkannya, Azha sangat sabar, ia sengaja mengunggu sampai ada diskon. Lumayan, menahan diri sementara tapi untung dua kali lipat, discount-nya $50 \%$. Azha bergoyanggoyang senang. Dan sepatu, dia membuka kantong sepatu tumit tinggi bertali-tali yang tadi sempat jadi rebutan sama cewek lain yang juga tertarik dengan sepatu yang sama. Sama-sama tangan mereka terulur untuk mengambil sepatu itu, tapi dengan memanfaatkan wajah kondangnya, Azha tersenyum, "Saya duluanMbak, sori." (Arifin, 2003:38).

\section{a) Kongko-kongko (Hang-out)}

Kongko-kongko adalah duduk santai dengan pembicaraan yang tidak menentu ujung pangkalnya (beberapa orang bersama-sama). Di dalam cerita, para perempuan muda dan mapan membentuk sebuah kelompok yang diberi nama BITCH. Dari namanya saja sudah menunjukkan satu identitas yang terkesan garang. Bitch bermakna jalang, dan dari keseluruhan cerita para anggota kelompok BITCH ini bisa dikatakan mewakili makna yang disandangnya.

Selanjutnya, tempat berkumpul kelompok ini -sebagai kelompok perempuan muda, mapan, dan bebas- bukanlah tempat yang seadanya. Untuk menunjukkan keberadaan identitasnya, tempat untuk kongko-kongko yang mereka pilih tentunya juga harus mentereng dan bergengsi. Starbuck menjadi pilihan yang mewakili status mereka. Ingat, karya sastra ini diliris tahun 2003. Artinya, pada saat itu
Starbuck menjadi satu di antara sedikit tempat kongkonya mereka yang berkantong tebal. Hal ini tentu saja sudah sangat berbeda dengan era sekarang. Pada saat ini, Starbuck menjadi tempat kongko yang tetap elite, meskipun bukan menjadi sedemikian eksklusif seperti dulu.

Starbuck, Sabtu sore. Ini hari berkumpul BITCH girl, katanya sih kepanjangan dari beautiful, intelligent, talented, charming and 'hot'. (Arifin, 2003:38).

Sebagai sebuah identitas kelas elite, Starbuck dipilih karena memiliki fasilitas yang dibutuhkan oleh mereka yang membutuhkan kenyamanan dan kesenangan (pleasure). Selain itu, Starbuck dipilih karena keelitannya. Para hedonis tidak akan asal memilih tempat kongko tanpa mempertimbangkan gengsi dan kehormatannya. Hedonis berharap menjadi pusat perhatian bagi siapa saja yang ada di sekitarnya.

Pelayan yang menyambut kedatangannya sudah hapal, segera membantu dan mengarahkannya ke sebuah pojok yang menjadi tempat favorit BITCH girl ngerumpi. Dia mengambil posisi di sudut luar yang tentu saja strategis untuk memperhatikan orang-orang yang lalu lalang di situ.

Pelayan menyodorkan menu list, namun tanpa membacanya lagi Azha langsung memesan minuman favoritnya, coffe latte. (Arifin, 2003:38).

Ketersediaan menu yang menjadi pilihan sekali pun juga bukanlah pilihan kelas rendah. Pada saat itu caffe latte terasa begitu prestisius. Hanya kalangan tertentu saja yang memiliki pilihan menu minuman seperti ini. dan, Azha memilihnya sebagai menu 
favorit setiap kali dia datang ke sana.

\section{b. Hedonisme Positif}

Hedonisme memberi kontribusi terhadap kebahagiaan. Alasan utamanya adalah bahwa kebahagiaan terlihat hasilnya dari keseimbangan positif dari pengalaman yang menyenangkan dibandingkan dari pengalaman-pengalaman lain yang tidak menyenangkan; misalnya jumlah kesenangan dan kesedihan, dan keseimbangan ini bisa lebih positif apabila seseorang mampu mencapai puncak kenikmatan (Veenhoven, 2003:439). Bagaimana hedonisme membantu perkembangan kebahagiaan? Dalam pandangan ini hedonisme seperti memberi kontribusi terhadap kebahagiaan. Alasan utamanya adalah bahwa kebahagiaan terlihat hasilnya dari keseimbangan positif dari pengalaman yang menyenangkan dibandingkan dari pengalamanpengalaman lain yang tidak menyenangkan; misalnya jumlah kesenangan dan kesedihan, dan keseimbangan ini bisa lebih positif apabila seseorang mampu mencapai puncak kenikmatan.

Selain pengaruh langsung ini, beberapa sumbangan tidak langsung bisa disebutkan di sini. Salah satu pengaruh tidak langsungnya adalah bahwa kenikmatan akan meningkatkan kapasitas seseorang untuk mengatasi permasalahan hidup, misalnya dengan memelihara toleransi antarindividu saat dalam tekanan dan dengan meningkatkan kontrol realitas terhadap emosi yang sedang dialaminya (Iversen dan Erwin dalam Veenhoven, 2003:440). Pengaruh tidak langsung lainnya adalah bahwa kenikmatan akan membuat manusia semakin bersosialisasi. Kita berbincang dan tertawa banyak dengan segelas anggur dan makanan yang lezat. Ini dilihat sebagai upaya untuk memperkuat ikatan sosial, yang akan menjadi pijakan bagi pengalaman yang lebih menyenangkan di masa mendatang. Hedonisme juga dipercaya berkontribusi terhadap kebahagiaan dengan pengaruh positifnya tersebut terhadap kesehatan fisik (Warburton dan Sherwood, dalam Veenhoven, 2003:441).

Hedonisme positif yang ada di dalam cerita Suatu Sore adalah adanya keinginan untuk (a) menjadi pusat perhatian, (b) solidaritas, dan (c) pola pergaulan. Kesenangan bersifat membahagiakan tidak harus sampai membahayakan diri sendiri, apalagi orang lain. Gambaran lebih luas dari masingmasing poin ini akan dijelaskan berikut ini.

\section{1) Pusat Perhatian}

Salah satu yang menjadi ciri kesenangan (pleasure) untuk menjadi pusat perhatian di dalam cerita ini adalah adanya penggunaan bahasa, selain aksesoris-aksesoris lain yang secara fisik langsung terlihat dari penampilan apa yang menempel pada para tokoh cerita. Penampilan fisik bisa didukung dengan sisi komsumtif masing-masing tokoh. Hal lain yang menjadikan seseorang atau kelompok menjadi pusat perhatian adalah dari penggunaan bahasa yang dipilihnya. Hal ini pulalah yang terjadi di dalam cerita pendek yang melibatkan kelompok BITCH ini.

Penggunaan bahasa asing (dalam hal ini bahasa Inggris) yang banyak dipergunakan di dalam keseluruhan cerita ini mencirikan hedonisme yang ada. Mulai dari BITCH yang memiliki kepanjangan beautiful, intelligent, talented, charming and 'hot' (cantik, pintar, berbakat, cakep, dan panas/seksi). Seperti sudah disampaikan sebelumnya, bitch itu sendiri bermakna jalang.Ada juga penggunaan bahasa Inggris di dalam cerita ini yangmenunjukkan kualitas pergaulan para tokohnya, seperti di bawah ini.

Yang pertama muncul Azha, penulis dan presenter TV yang kondang karena gayanya yang cool dan smart. Saking coolnya, dia suka dituduh lesbi. Hobby banget belanja, makanya suka 
kesasar ke Plaza Senayan kalau ada sale. Artinya orang susah menghubungi dia kalau dia lagi belanja, even produser TV-nya sendiri. Jadi anggap aja dia kesasar dan menghilang. Seperti biasa, dia muncul dengan kantong-kantong belanjaan. (Arifin, 2003:38).

Ada cool (keren atau dingin) dan smart (cerdas), hobby (kegemaran, kesukaan, hobi), sale (obral), dan even (bahkan). Selain itu, ada juga menu list (daftar menu, daftar makanan) dan juga coffe latte (kopi latte). Juga, discount (diskon, rabat, potongan, korting), blouse (blus), simple (simpel, sederhana), dan casual (kasual, sederhana, biasa saja) seperti di bawah ini.

Pelayan menyodorkan menu list, namun tanpa membacanya lagi Azha langsung memesan minuman favoritnya, coffe latte. (Arifin, 2003:38).

Lumayan, menahan diri sementara tapi untung dua kali lipat, discount-nya $50 \%$. Berbeda dengan kedua temannya yang suka pake baju-baju seksi dan gila merek, Rae lebih konservatif, koleksi bajunya adalah blouse berpotongan simple dengan kombinasi celana panjang casual. (Arifin, 2003:38).

Dengan penggunaan bahasa yang berbau asing seperti di atas, seolah menunjukkan bahwa mereka berasal dari suatu kelompok sosial tertentu, dalam hal ini adalah kelompok elite. Hanya mereka yang memiliki kemampuan, dan kesempatan lebih, untuk mengaplikasikan kemampuannya di dalam menggunakan bahasa asing.

\section{2) Solidaritas}

Di dalam pembahasan bagian solidaritas ini akan digambarkan bagaimana kesetiakawanan yang ramai dan erat di antara mereka. Solidaritas atau kesetiakawanan yang kuat di antara mereka ditandai dengan solidaritas tentang shopping dan seksualitas. Solidaritas tentang shopping banyak didapat dari Azha sedangkan solidaritas tentang seksualitas didapat dari Sendre yang banyak membantu memberi informasi tentang seksualitas.

Kebiasaan Azha dalam hal shopping sudah dibahas pada bagian hedonisme negatif (perilaku konsumtif) di poin (a) perilaku belanja (shopping). Kebiasaan shopping Azha yang seperti ini banyak menjadi rujukan bagi teman-temannya untuk melakukan hal yang sama seperti apa yang dilakukannya.

Di sisi lain, Sendre banyak menularkan ilmunya tentang seksualitas. Dialah yang membuka pembicaraan tentang cunnilingus dan waxing. Sendre yang memberi keterbukaan tentang kesenangan dan kenikmatan seksual untuk bisa mendapatkan kepuasan. Seksualitas bukan sekadar hubungan kelamin yang tidak bermakna dan tidak meninggalkan kesan mendalam. Sudah seharusnya seksualitas menyertakan gairah yang bagus, yang didukung oleh perangkat-perangkat seksualitas yang bisa dipersiapkan sebelumnya dengan sebaik-baiknya. Apabila Azha sudah mempersiapkan diri dengan pakaian dalam yang dianggap akan meningkatkan gairah seksualitas dirinya dengan pasangannya maka Sendre melakukan aktivitas seksualitas dengan praktek cunnilingus dan waxing.

Yang perlu mendapat tekanan di sini adalah bagaimana solidaritas atau kesetiakawanan di antara mereka di dalam berbagi segala hal akan menjadi nilai positif di dalam aktivitas pertemanan mereka. Dengan kedua hal tersebut, shopping dan seksualitas ini, menjadikan solidaritas atau kesetiakawanan di antara anggota $\mathrm{BITCH}$ semakin menjadi erat. 
Kesenangan yang menjadikan mereka tetap berteman dan bersahabat. Kesenangan yang penuh dengan kemewahanlah yang menjadikan mereka tetap menjalani kebersamaan itu. Coba perhatikan andai mereka tidak memiliki kesenangan yang sama akan kemewahan, kebebasan, dan kemapanan yang sama.

\section{3) Pergaulan}

Sebuah pergaulan tingkat elite yang tidak semua orang bisa melakukannya. Hanya orang-orang berduit, berkantong tebal, dan bebas yang bisa melakukan pola pergaulan sepert ini. Dengan solidaritas yang bagus pergaulan di antara mereka juga berjalan dengan sedemikian positif. Di antara para anggota sudah menyadari bagaimana bergaul dengan nyaman dan menyenangkan. Hal ini bisa dipahami karena masing-masing pihak memiliki latar belakang kehidupan dan keinginan yang sama (setidaknya mirip) sehingga memudahkan untuk melakukan pergaulan yang sama. Tidak ada permasalahan yang timbul di antara mereka karena yang mereka inginkan hanyalah kesenagan (pleasure) dan hal-hal lain yang mendukung untuk mendapatkan dan merealisasikan kesenangan tersebut.

Pergaulan di antara mereka semata didasari oleh keinginan untuk bersenang-senang. Hasil dari bersenang-senang itu adalah sebuah silaturahim yang terus terjalin dan terjaga, keterbukaan untuk sesuatu yang baru yang akan terus bisa dilakukan, dan hal-hal lain yang akan mendukung keberhasilan para anggota ini di dalam kehidupannya, termasuk karir dan perjodohan mereka.

Ah, BITCH Girl. Pembicaraan mereka memang berkisar pada masalah yang seru-seru. Kadangkadang mereka bicara hal-hal yang lebih seru dan serius dari sekadar hubungan seks, tapi tetap saja, membicarakan seks memang menyenangkan dan selalu jadi awal pembicaraan berikutnya. (Arifin, 2003:43).

Semua hanya demi kesenangan. Mereka tidak perduli berapa rupiah yang harus dikeluarkan. Mereka juga menginginkan kebebasan seperti yang mereka idamkan. Keinginan untuk bergaul ini menjadi tidak menjadi permasalahan. Akan menjadi permasalahan apabila keinginan ini mereka realisasikan, mereka lakukan.

\section{DAFTAR PUSTAKA}

Arifin, Nurul. 2003. "Suatu Sore" dalam Cosmo's Short Stories: Kumpulan Cerita Pendek Pilihan Cosmopolitan. Jakarta: Cosmopolitan.

Bertens, K. 2013. Etika. Yogyakarta: Penerbit Kanisius.

Brax, David. 2009. Hedonism as the Explanation of Value. Stockhom: Media-Tryck Sociologen.

Cahyono, J.B. Suharjo. 2008. Gaya Hidup dan Penyakit Modern. Yogyakarta: Kanisius.

Dawson, Catherine. 2010. Metode Penelitian Praktis: Sebuah Panduan. Yogyakarta: Pustaka Pelajar.

Dewojati, Cahyaningrum. 2010. Wacana Hedonisme dalam Sastra Populer Indonesia. Yogyakarta: Pustaka Pelajar.

Faruk. 2015a. Pengantar Sosiologi Sastra: dari Strukturalisme Genetik sampai PostModernisme. Yogyakarta: Pustaka Pelajar.

Faruk. 2015b. Metode Penelitian Sastra: Sebuah Penjelajahan Awal. Yogyakarta: Pustaka Pelajar.

Jabrohim (Ed.). 2012. Teori Penelitian Sastra. Yogyakarta: Kerja sama antara Masyarakat Poetika Indonesia dengan Pustaka Pelajar.

Kaul, Subhashini. 2007. Hedonism and Culture: Impact on Shopping Behaviour, A Research Agenda. Dalam Vikalpa, Volume 32 Nomor 3, 
hlm. 81-89.

Kunzmann, U., Stange, A., dan Jordan J. 2005. Possitive Affectivity in Adulthood: Do You Do What You Feel?. Dalam Personality and Social Psychology Bulletin, Vo. 3 No. 4, April 2005, hIm. 574-588.

Nabella, Mentari Ghea. 2017. "Gaya Hidup Hedonis pada Mahasiswi Muslim yang Melakukan Aktifitas Clubbing". Skripsi di Program Studi Psikologi Islam, Fakultas Psikologi, Universitas Islam Negeri Raden Fatah Palembang. Palembang: Tidak Diterbitkan.

Margono, S. 2007. Metologi Penelitian Pendidikan Komponen MKDK. PT. Rineka Cipta, Jakarta.

Moeliono, Anton A., dkk. 1989. Kamus Besar Bahasa Indonesia. (Cetakan ke-2). Jakarta: Balai Pustaka.

Moleong, Lexy J. 2016. Metodologi Penelitian Kualitatif. Bandung: Remaja Rosdakarya.

Ratna, Nyoman Kutha. 2010. Sastra dan Cultural Sudies: Representasi Fiksi dan Fakta. Yogyakarta: Pustaka Pelajar.

Ratna, Nyoman Kutha. 2011. Antropologi Sastra: Peranan dan Unsur-unsur Kebudayaan dalam Proses Kreatif. Yogyakarta: Pustaka Pelajar.

Ratna, Nyoman Kutha. 2015. Teori, Metode, dan Teknik Penelitian Sastra: dari Strukturalisme hingga Postrukturalisme, Perspektif Wacana Naratif. Yogyakarta: Pustaka Pelajar.

Saputri, Ardilla dan Rachmatan, Risana. 2016. Religiusitas dengan Gaya Hidup Hedonisme: Sebuah Gambaran pada Mahasiswa Syiah Kuala. Dalam Jurnal Psikologi, Volume 12 Nomor 2, Desember 2016, hlm. 59—67.

Stanton, Robert. 2012. Teori Fiksi Robert Stanton. Yogyakarta: Pustaka Pelajar.

Strinati, Dominic. 2007. Popular Culture: Pengantar Menuju Teori Budaya Populer. Bandung: Jejak.

Suyanto, Bagong. 2013. Sosiologi Ekonomi: Kapitalisme dan Konsumsi di Era Masyarakat Post-Modernisme. Jakarta: Kencana Prenada Media Group.

Trimartati, Novita. 2014. Studi Kasus tentang Gaya Hidup Hedonisme Mahasiswa Bimbingan dan Konseling Universitas Ahmad Dahlan. Dalam Jurnal PSIKOPEDAGOGIA Vol. 3 No. 1, hlm.
$20-28$.

Veenhoven, Ruut. 2003. Hedonism and Happiness. Dalam Journal of Happiness Studies 4: 437457, 2003

Weijers, Daniel Michael. 2012. Hedonism and Happines in Theory and Practice. Wellington: Victoria University of Wellington.

Wellek, Rene dan Warren, Austin. 2014. Teori Kesusastraan. Jakarta: Penerbit PT Gramedia Pustaka Utama. 
